medRxiv preprint doi: https://doi.org/10.1101/2021.04.08.21255167; this version posted April 13, 2021. The copyright holder for this preprint

(which was not certified by peer review) is the author/funder, who has granted medRxiv a license to display the preprint in perpetuity.

It is made available under a CC-BY-NC-ND 4.0 International license .

\title{
Refining "long-COVID" by a prospective multimodal evaluation of patients with long- term symptoms related to SARS-CoV-2 infection
}

\section{Running title: Multimodal evaluation of "long-COVID"}

Marc Scherlinger (0000-0002-9453-5895)* 1,2 , Renaud Felten*1,2 ${ }^{1}$ Floriane Gallais $*^{3}$, Charlotte Nazon ${ }^{3}$, Emmanuel Chatelus ${ }^{1,2}$, Luc Pijnenburg ${ }^{1,2}$, Amaury Mengin ${ }^{4}$, Adrien Gras ${ }^{4}$, Pierre Vidailhet ${ }^{4}$, Rachel Arnould-Michel ${ }^{1,2}$, Sabrina Bibi-Triki ${ }^{5}$, Raphä̈l Carapito ${ }^{5}$, Sophie Trouillet-Assant ${ }^{6}$, Magali Perret ${ }^{6}$, Alexandre Belot ${ }^{6}$, Seiamak Bahram ${ }^{5}$, Laurent Arnaud ${ }^{1,2,5}$, Jacques-Eric Gottenberg ${ }^{1,2,7}$, Samira Fafi-Kremer ${ }^{\# 3,5}$ \& Jean Sibilia ${ }^{\# 1,2,5}$

\section{"Participated equally in the study.

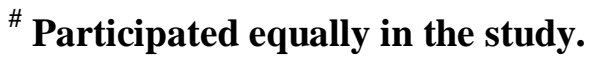

\section{Affiliations:}

1 Rheumatology Department, Centre Hospitalier Universitaire de Strasbourg, 1 avenue Molière, 67098 Strasbourg, France

2 Centre National de Référence des Maladies Auto-Immunes et Systémiques Rares, Est/SudOuest (RESO), France

3 Virology diagnostic laboratory, Centre Hospitalier Universitaire de Strasbourg, 3 Rue Koeberlé, 67000 Strasbourg, France

4 Psychiatry department, Centre Hospitalier Universitaire de Strasbourg, 1 avenue Molière, 67098 Strasbourg, France

5 Laboratoire d'ImmunoRhumatologie Moléculaire, Institut national de la santé et de la recherche médicale (INSERM) UMR_S 1109, Institut thématique interdisciplinaire (ITI) de Médecine de Précision de Strasbourg, Transplantex NG, Faculté de Médecine, Fédération Hospitalo-Universitaire OMICARE, Fédération de Médecine Translationnelle de Strasbourg (FMTS), Université de Strasbourg, Strasbourg, France.

6 National Reference centre for Rare rheumatic and AutoImmune diseases in childrEn RAISE, Hospices Civils de Lyon, CIRI, Centre International de Recherche en Infectiologie, Inserm, U1111, Université Claude Bernard Lyon 1, CNRS, UMR5308, ENS de Lyon, F69007, Lyon, France 7 IBMC, UPR3572, CNRS, Strasbourg, France

Word count $: 2936$

Figure count : 4

Table count: 2

Keywords: SARS-CoV-2; long-COVID; patient perspective; pain; disability

Corresponding authors: Prof. Jean Sibilia, M.D. Ph.D. and Marc Scherlinger, M.D. Ph.D.

Centre national de référence maladie auto-immunes et systémiques rares Est/Sud-Ouest (RESO), Service de Rhumatologie du CHU de Strasbourg. 1 Avenue Molière, 67200 Strasbourg Cedex. Telephone number: + 333881284 74. Fax number: + 33388128290 Email :jean.sibilia@chru-strasbourg.fr and marc.scherlinger@chru-strasbourg.fr 
45 Acknowledgments: We thank all patients who agreed to take part in the study. We thank

46 Valle Meyer for her precious help in planning the study and patient communication. We also 47 thank COVID-HUS for its support.

48 Conflicts of interest: SFK has received speakers fees from BMS and Roche.

49

50

Key points:

- Among 30 consecutive patients reporting persistent symptoms (median 6 months) self-attributed to COVID-19, pain, fatigue and disability were reported in virtually all patients.

- More than one third of patients suffer from psychological disorders such as anxiety, depression and/or post-traumatic stress disorder, regardless of SARS-CoV-2 immunity.

- At the time of evaluation, only $50 \%$ of patients had cellular and/or humoral sign of a past SARS-CoV-2, and serology positivity varied depending of the kit used.

- Exhaustive clinical, biological and immunological evaluations failed to find an alternative diagnosis, or to identify specific cytokine signature including type I interferon. 
medRxiv preprint doi: https://doi.org/10.1101/2021.04.08.21255167; this version posted April 13, 2021. The copyright holder for this preprint

\section{Abstract}

67

68 Background: COVID-19 long-haulers or "long-COVID" represent 10\% of COVID-19

69 patients and remain understudied.

70 Methods: In this prospective study, we recruited 30 consecutive patients seeking medical

71 help for persistent symptoms (> 30 days) attributed to COVID-19. All reported a viral illness

72 compatible with COVID-19. The patients underwent a multi-modal evaluation including

73 clinical, psychological, virological, specific immunological assays and were followed

74 longitudinally.

75 Results The median age was 40 [interquartile range: $35-54$ ] and 18 (60\%) were female. After

76 a median time of 152 [102-164] days after symptom onset, fever, cough and dyspnea were

77 less frequently reported as compared with the initial presentation, but paresthesia and burning

78 pain emerged in $18(60 \%)$ and $13(43 \%)$ patients, respectively. The clinical examination was

79 unremarkable in all patients although the median fatigue and pain visual analogic scales were

$807[5-8]$ and $5[2-6]$, respectively.

81 Extensive biological studies were unremarkable, as were multiplex cytokine and ultra-

82 sensitive interferon-a2 measurements. At this time, nasopharyngeal swab and stool RT-PCR

83 were negative for all tested patients. Using SARS-CoV-2 serology and IFN- $\gamma$ ELISPOT, we

84 found evidence of a previous SARS-CoV-2 infection in 50\% (15/30) of patients, with

85 objective evidence of lack or waning of immune response in two. Finally, psychiatric

86 evaluation showed that $11(36.7 \%), 13(43.3 \%)$ and $9(30 \%)$ patients had a positive screening

87 for anxiety, depression and post-traumatic stress disorder, respectively.

88 Conclusions Half of patients seeking medical help for long-COVID lack SARS-CoV-2

89 immunity. The presence of SARS-CoV-2 immunity did not cluster clinically or biologically

90 long haulers, who reported severe fatigue, altered quality of life, and exhibited psychological

91 distress. 
medRxiv preprint doi: https://doi.org/10.1101/2021.04.08.21255167; this version posted April 13, 2021. The copyright holder for this preprint (which was not certified by peer review) is the author/funder, who has granted medRxiv a license to display the preprint in perpetuity.

It is made available under a CC-BY-NC-ND 4.0 International license .

\section{Introduction}

93 After SARS-CoV-2 infection, some patients may continue to experience symptoms for

94 months (1), a condition called "long-COVID" or "COVID-19 long-haulers" (2). These long-

95 term symptoms contribute to the worldwide COVID-19 burden and have been extensively

96 communicated by the patients and some physicians $(3,4)$. Long-COVID manifestations are

97 clinically diverse, and their underlying mechanisms are likely to be multiple. Patients who

98 underwent long hospitalization because of severe disease may exhibit lung or heart chronic

99 injury due to the severe immune response $(5,6)$, micro- or macrovascular thrombotic

100 neurological complications (7), and/or physical deconditioning (8). Indeed, a recent cohort

101 study found that among 1733 hospitalized COVID-19 patients, 76\% reported at least one

102 symptom after 6 months, and objective pulmonary abnormalities were found in more than

$10320 \%$ (9). However, these pathological mechanisms are less likely to explain the

104 manifestations in patients with initially non-severe COVID-19 who experience long-lasting

105 symptoms. Although 10\% of COVID-19 patients may show chronic symptoms (>12 weeks)

106 (10), only scarce data are available on the clinical presentation, biological characteristics and

107 overall prognosis of such patients $(11,12)$. Moreover, the virological definition of the long-

108 COVID entity in terms of serology and other specific immunological assays is still not

109 precisely established $(11,13)$.

110 The aim of our study was to refine the clinical and biological characteristics of long-COVID

111 by conducting a multimodal evaluation of consecutive patients seeking medical help for 112 persistent symptoms attributed to COVID-19 (long-COVID). 
medRxiv preprint doi: https://doi.org/10.1101/2021.04.08.21255167; this version posted April 13, 2021. The copyright holder for this preprint (which was not certified by peer review) is the author/funder, who has granted medRxiv a license to display the preprint in perpetuity.

It is made available under a CC-BY-NC-ND 4.0 International license .

\section{Methods}

115 Patients and ethical considerations

116 We included 34 consecutive patients seeking medical help for persistent symptoms attributed

117 to COVID-19 for a systematic prospective study. Patients were recruited in the "Grand-Est"

118 region of France, the area with the highest incidence of SARS-CoV-2 infection during the

119 first epidemical wave in France (February to April 2020) (14). Information about a long-

120 COVID consultation in our tertiary center was advertised through local media and social

121 networks, and consulting patients were then asked to participate in the study. All patients

122 provided written informed consent. Age-matched patients with a history of non-severe

123 COVID-19 (positive humoral and cellular response) without persistent symptoms were

124 controls for the immunological assays. This study is part of the "COVID-HUS" study, which

125 was approved by the ethics committee of the University Hospital of Strasbourg (NCE-2020-

$12651)$.

127

128

Medical evaluation

129 All patients were evaluated at our reference center for rare systemic and autoimmune

130 diseases. Five physicians (MS, RF, EC, LP and JS) conducted the clinical evaluation with a

131 physical examination and a standardized questionnaire on medical and SARS-CoV-2-related

132 infection history. Dedicated questionnaires were used to evaluate subjective symptoms: DN4

133 for neuropathic pain (15), Fibromyalgia Rapid Screening Tool (FiRST (16)) and visual

134 analog scales for fatigue/pain/dryness. Additionally, patients underwent systematic blood

135 testing to rule out alternative diagnoses (full list in supplementary file 1).

136

137 Virologic and immunologic evaluation 
medRxiv preprint doi: https://doi.org/10.1101/2021.04.08.21255167; this version posted April 13, 2021. The copyright holder for this preprint (which was not certified by peer review) is the author/funder, who has granted medRxiv a license to display the preprint in perpetuity.

It is made available under a CC-BY-NC-ND 4.0 International license.

138 Blood samples were collected at the same time as the clinical evaluation for immuno-

139 virologic assays. The testing included extensive serology evaluation with 4 commercial

140 assays. One lateral flow assay tested for the receptor binding 2 (RBD) of the spike protein as

141 an antigenic source (Biosynex BSS IgM/IgG assay), and two enzyme-linked immunosorbent

142 assays (ELISA) targeted the RBD (Wantai total antibody) and the S1 domain (Euroimmun

143 IgG). Finally, ELISA was used to detect anti-nucleocapsid (anti-N) IgG (Abbott Architect

$144 \mathrm{IgG})$. To explore the SARS-CoV-2-specific T-cell response, heparin-anticoagulated blood

145 tubes were collected for interferon gamma (IFN- $\gamma$ ) enzyme-linked immunospot (ELISPOT)

146 assay. Peripheral blood mononuclear cells were isolated by using Ficoll-Paque gradient, and

$147 \mathrm{CD}^{+}$cell frequencies were measured by flow cytometry. Anti-IFN- $\gamma$ antibody-coated wells

148 (UCytech) were seeded with $200,000 \mathrm{CD}^{+}$cells per well. Cells were stimulated in duplicate

149 with overlapping 15-mer peptide pools spanning SARS-CoV-2 structural proteins (spike

150 protein [S1 and S2], nucleoprotein, membrane and envelope proteins) and accessory proteins

151 (NS3, NS7A, NS8, NS9B) as well as the spike glycoprotein of human coronaviruses 229E

152 (ES1, ES2) and OC43 (OS1, OS2) (PepMix, JPT Peptide Technologies). Culture medium

153 was a negative control and phytohemagglutinin (PHA) a positive control. Peripheral blood

154 mononuclear cells were cultured overnight ( $20 \pm 4 \mathrm{hr}$ ) before enzymatic revelation of IFN- $\square$

155 capture (UCytech). Spots were counted by using an ELISPOT reader (AID) and results are

156 expressed as mean number of spot-forming units $/ 10^{6} \mathrm{CD}^{+}$cells after subtraction of the

157 background value. Positivity was defined as a T-cell response $\geq 3$ times the standard

158 deviation of the negative controls. To complete the immunological evaluation, IFN- $\alpha 2$ (with

159 Single Molecule Array; SIMOA, Quanterix (17)) and cytokines (with a custom multiplex

160 cytokine assay; Luminex Thermo Fisher) were measured from serum samples.

161

162

Psychological evaluation 
medRxiv preprint doi: https://doi.org/10.1101/2021.04.08.21255167; this version posted April 13, 2021. The copyright holder for this preprint

(which was not certified by peer review) is the author/funder, who has granted medRxiv a license to display the preprint in perpetuity.

It is made available under a CC-BY-NC-ND 4.0 International license .

163 A standardized interview was conducted by a clinical psychologist (R.A-M). The interview

164 aimed at evaluating psychiatric history and treatments, presence of sleep issues and increase

165 of toxic or anxiolytic use. The impact of the COVID-19 pandemic on quality of life was

166 assessed by using the Medical Outcomes Study 36-item Short-form (SF-36) and Health

167 Assessment Questionnaire (HAQ). Patients' perspectives on the pandemic crisis were

168 assessed. Finally, validated translated questionnaires were used to screen for

169 anxiety/depression (Hospital Anxiety and Depression Scale [HADS-A/D]) and post-traumatic

170 stress disorder (PTSD checklist [PCL-5] for the Diagnostic and Statistical Manual of Mental

171 Disorders, Fifth edition [DSM-5]). Positive screening for these mental disorders was

172 confirmed with a score $\geq 10$ for HADS-Anxiety, $\geq 7$ for HADS-Depression (18), and $\geq 31$ for

173 PCL-5 (19).

174

175 Statistics

176 Quantitative data are reported with median (interquartile range [IQR]) and were compared by

177 non-parametric Mann-Whitney test. Categorical data are reported with number (\%) and were

178 compared by chi-square or Fisher exact test, as appropriate. To compare initial and persistent

179 clinical features, McNemar's test was used with Bonferroni's correction for multiple testing.

180 Statistical analyses involved using GraphPad Prism 7.0. P < 0.05 was considered statistically

181 significant.

182

183 
medRxiv preprint doi: https://doi.org/10.1101/2021.04.08.21255167; this version posted April 13, 2021. The copyright holder for this preprint (which was not certified by peer review) is the author/funder, who has granted medRxiv a license to display the preprint in perpetuity.

It is made available under a CC-BY-NC-ND 4.0 International license .

\section{Results}

185 Patients

186 A total of 34 consecutive patients seeking help for persistent symptoms attributed to COVID-

18719 visited to our center between June and August 2020; 30 were included in the study.

188 Reasons for non-inclusion were refusal of physical consultation because of geographical

189 distance $(n=3)$, spontaneous improvement of the condition $(n=1)$. In total, $60 \%$ were women

190 (18/30) and the median age was 40 years (IQR 35-54). The cohort included 2 married

191 couples, and other patients were unrelated. Before the initial presentation, none of the patient

192 reported chronic pain nor the use of analgesics. Other characteristics are in Table 1.

193

\section{Initial presentation}

195 All patients declared a viral illness compatible with COVID-19. Initial symptoms occurred

196 between 1 February and 9 April 2020 and were mainly characterized by fever (60\%), myalgia

197 (76.7\%), cough (73.3\%) and anosmia (43.3\%) (Figure 1). Among 9 patients who underwent

198 nasopharyngeal SARS-CoV-2 RT-PCR within 5 weeks after symptom onset, 55.6\% (5/9) had

199 a positive result and all RT-PCR tests conducted after this time were negative $(n=11)$. Seven

200 patients consulted in the emergency department, and one was hospitalized in a conventional

201 hospital unit to receive oxygen for 7 days, without specific treatment. All other patients were

202 cared for at home. A total of 13 patients were prescribed treatments: 2 received

203 hydroxychloroquine $400 \mathrm{mg} /$ day, 4 prednisone $1 \mathrm{mg} / \mathrm{kg}$ for $5-7$ days, 8 antibiotics

204 (azithromycin, $\mathrm{n}=6$; amoxicillin, $\mathrm{n}=2$ ) and 2 low-dose aspirin. The other 17 patients

205 received only symptomatic treatment (acetaminophen).

206 
medRxiv preprint doi: https://doi.org/10.1101/2021.04.08.21255167; this version posted April 13, 2021. The copyright holder for this preprint (which was not certified by peer review) is the author/funder, who has granted medRxiv a license to display the preprint in perpetuity.

It is made available under a CC-BY-NC-ND 4.0 International license .

207

208 Patients were clinically evaluated after a median of 152 days (IQR 102-164) after the

209 reported initial symptom onset. Seventeen (56.7\%) reported a resolution of initial symptoms

210 after a median of 21 days (IQR 15-33), followed by a resurgence after a median of 21 days

211 later (IQR 15-44). Conversely, the 13 other patients had no free-symptom intervals. Persistent

212 symptoms had a cyclical pattern in 28 (93.3\%) patients and were mostly represented by

213 fatigue, myalgia and thoracic oppression (Figure 1A). Fever, shivering and cough were

214 significantly less frequent as compared with the initial presentation $(\mathrm{p}<0.005$ for all; Figure

215 1A). Fatigue was severe for most patients and rated at a median of 7 (IQR 5-8) on a 10-point

216 scale, with pain rated at 5 (IQR 2-6).

217 Overall, $60 \%$ and $43.4 \%$ of patients exhibited diffuse paresthesia and burning pain later after

218 the initial presentation (Figure 1A). The DN4 questionnaire screening neuropathic pain was

219 positive $(\geq 4 / 10)$ for $50 \%(15 / 30)$ of patients and the FiRST questionnaire screening for

220 fibromyalgia-like symptoms was positive $(\geq 5 / 6)$ for $56.6 \%(17 / 30$; supplementary figure

221 1).

222 The clinical examination including neurological examination was unremarkable. At this time,

223 no patients received corticosteroids, non-steroidal anti-inflammatory drugs or opioids.

224 Finally, $16(53.3 \%)$ patients reported a trend toward a decrease of symptoms over time.

225

226 Virologic and specific immunologic evaluation

227 Specific analyses related to SARS-CoV-2 infection were conducted at a median of 174 days

228 (IQR 144-215) after symptom onset. At this time, in $18(60 \%)$ and 6 (20\%) of patients

229 underwent nasopharyngeal and stool RT-PCR for SARS-CoV-2; all tests were negative.

230 Exploration of the cellular immune response by SARS-CoV-2 IFN- $\gamma$ ELISPOT assay

231 revealed that $15(50 \%)$ patients had a positive response to at least SARS-CoV-2 nucleocapsid 
medRxiv preprint doi: https://doi.org/10.1101/2021.04.08.21255167; this version posted April 13, 2021. The copyright holder for this preprint (which was not certified by peer review) is the author/funder, who has granted medRxiv a license to display the preprint in perpetuity.

It is made available under a CC-BY-NC-ND 4.0 International license .

232 and spike proteins (considered ELISPOT-positive, Figure 2A). Among ELISPOT-positive 233 patients, $73.3 \%(11 / 15)$ also had a cellular response against non-structural SARS-CoV-2 as

234 compared with only $1(6.7 \%)$ of ELISPOT-negative patients $(\mathrm{p}<0.0001)$. Cellular response

235 to the spike protein of human coronavirus 229E and OC43 was similar in both SARS-CoV-2

236 ELISPOT groups (E+100\% vs E- $86.7 \%$ and $\mathrm{E}+80 \%$ vs $\mathrm{E}-73.3 \%)$.

237 Among patients with a negative IFN- $\gamma$ ELISPOT result, all but one had negative serology

238 results (Figure 2A). This patient had an isolated anti-S IgG assay. Among the 15 patients 239 with a positive IFN- $\gamma$ ELISPOT result, all had at least one positive serological assay. In 240 detail, $14(93.3 \%)$ had a positive result for anti-RBD total antibodies, $11(73.3 \%)$ anti-RBD 241 IgG/IgM, 12 (80\%) anti-S IgG and 11 (73.3\%) anti-N IgG (Figure 2A). We dichotomized the 242 patients into an immunized group (ELISPOT-positive and at least one positive serological 243 assay, $n=15$ ) and a non-immunzed group (ELISPOT-negative, $n=15$; Figure 2B), with 244 little difference in terms of symptoms (Figure 1B).

245 One ELISPOT-positive patient showed a decreasing signal for anti-N (equivocal to negative) 246 and anti-S signal (positive to equivocal) between day 133 and day 251. Additionally, one 247 patient with negative results for both IFN- $\gamma$ ELISPOT and serology assays (conducted 140 248 days after symptom onset) previously had a positive nasopharyngeal RT-PCR SARS-CoV-2 249 result early after the first symptoms (Figure 2B). This patient also had 2 negative $\operatorname{IgG}$ 250 serology tests for SARS-CoV-2 at 37 and 85 days after symptom onset (Biosynex ICT and 251 CLIA Cobas Roche, respectively).

252 IFN- $\alpha 2$ levels were similar for patients with persistent symptoms (regardless of their 253 immunity status) and those with a history of documented COVID-19 free of residual 254 symptoms (sampled > 12 weeks after infection; Figure 3). Other cytokine levels were low or 255 non-detectable and were similar between patients with and without immunization for SARS-

256 CoV-2 (Supplementary figure 2). 
medRxiv preprint doi: https://doi.org/10.1101/2021.04.08.21255167; this version posted April 13, 2021. The copyright holder for this preprint (which was not certified by peer review) is the author/funder, who has granted medRxiv a license to display the preprint in perpetuity.

It is made available under a CC-BY-NC-ND 4.0 International license .

Biological evaluation

259 Biological analyses (supplementary file 1) were conducted at the same time as the clinical 260 evaluation (152 days [IQR 102-164] after initial presentation). Routine biological test results 261 were within normal limits for all but one patient (an iron-deficiency anemia that was further

262 investigated and corrected). Values for markers of cardiac and muscle injury (troponin and 263 creatine phosphokinase) and coagulopathy (D-dimers, fibrinogen) were normal, and serology 264 for HIV, hepatitis C virus and Lyme disease was negative for all patients.

265 Screening for autoimmunity revealed low (1/160) and medium (1/320 to 1/640) titers of anti-

266 nuclear antibodies in 12 and 3 patients, respectively. Low to medium anti-nuclear antibody 267 titers were numerically more prevalent in SARS-CoV-2 immunized than non-immunized 268 patients $(66.7 \%$ vs $33.3 \%, \mathrm{p}=0.067)$. Screening for anti-extractable nuclear antigens, anti269 double-stranded DNA, anti-citrullinated protein and anti-neutrophil cytoplasmic antibodies as 270 well as rheumatoid factor was negative for all patients. Eight patients (4 in each 271 immunization group) showed isolated low titers ( $<3$ times normal range) of anti-cardiolipin 272 antibodies, with no history of thrombosis (IgM for 6, IgG for 2), and one patient was positive 273 for lupus anticoagulant. After 12 weeks, the repeat antiphospholipid antibodies testing was 274 negative for all patients.

276 Psychological evaluation

277 The phone interview by a clinical psychologist took place after a median of 224 days [202278238 ] after initial symptom onset. In all, 10\% (3/30) and 26.7\% (8/30) of patients had a history 279 of depression and anxiety disorders, respectively. Sleep issues were reported by 23 (73.3\%) 280 patients, and 4 (13.3\%) had started an anxiolytic prescriptions (Table 2); 5 (16.7\%) and 7 281 (23.3\%) reported loss of employment and financial difficulties. 
medRxiv preprint doi: https://doi.org/10.1101/2021.04.08.21255167; this version posted April 13, 2021. The copyright holder for this preprint (which was not certified by peer review) is the author/funder, who has granted medRxiv a license to display the preprint in perpetuity. It is made available under a CC-BY-NC-ND 4.0 International license .

282 HADS screening for anxiety and depression was positive for $11(36.7 \%)$ and $13(43.3 \%)$ of

283 patients, respectively (Table 2). Using the PCL-5 questionnaire, 9 (30\%) patients had scores 284 compatible with PTSD (Table 2). These values did not differ by immunization status (Figure 285 4). Several components of the SF-36 scale, physical limitations, energy and pain, were 286 severely affected, with no significant difference between patients immunized or not for 287 SARS-CoV-2 (supplementary figure 3). Family, friends and colleagues were a major source 288 of support for $20(66.7 \%), 18(60 \%)$ and 11/25 (44\%) patients, respectively. Conversely, 7 289 (23.3\%) patients felt significant support by physicians. 
medRxiv preprint doi: https://doi.org/10.1101/2021.04.08.21255167; this version posted April 13, 2021. The copyright holder for this preprint (which was not certified by peer review) is the author/funder, who has granted medRxiv a license to display the preprint in perpetuity.

It is made available under a CC-BY-NC-ND 4.0 International license .

\section{Discussion}

292 In this study, we included 30 consecutive patients seeking medical help for persistent 293 symptoms (median 6 months) self-attributed to COVID-19. We identified two clinically

294 comparable groups of long-COVID: those with and those without objective SARS-CoV-2

295 immunity. In 93\% of patients, persistent symptoms had a cyclical pattern and were mostly

296 represented by fatigue, thoracic oppression, myalgia, paresthesia and burning pain, which

297 agrees with the literature (20,21). Dichotomizing patients by presence or not of anti-SARS-

298 CoV-2 immunity resulted in only small differences in clinical presentation (Figure 1B).

299 Indeed, both groups had high pain/fatigue indexes and limitations in several components of

300 the SF-36 scale (Supplemental Figures 1 and 3).

301 Only half of the patient had objective cellular (IFN- $\gamma$ ELISPOT-based) and humoral 302 immunity for SARS-CoV-2 (Figure 2B). There are three possible (and non-exclusive) 303 explanations for this result. First, some patients may have been infected with SARS-CoV-2, 304 without detectable immunity. As already described (22), one of our patients with RT-PCR305 proven SARS-CoV-2 infection had a negative SARS-CoV-2 serology result at several times

306 (36, 85 and 140 days after initial symptoms) as well as on IFN- $\gamma$ ELISPOT (after 140 days).

307 Second, immunity may have developed in some patients but subsequently waned over time, 308 although such reports are discordant $(23,24)$. In our cohort, one patient with PCR/ELISPOT309 confirmed infection showed IgG serology findings between days 133 and 251, both on anti-N

310 (from equivocal to negative) and anti-S (from positive to equivocal) ELISA. Additionally, 311 patients with cellular immunity might have negative serology, particularly anti-N $\operatorname{IgG}$

312 (Figure 2A). Finally, some patients may have presented a non-specific viral illness and

313 subsequent symptoms, which were falsely attributed to SARS-CoV-2. In fact, the period of 314 the first pandemic wave was highly anxiogenic and may have exacerbated pre-existing 315 psychological conditions and induced a nocebo effect in some patients (25). 
medRxiv preprint doi: https://doi.org/10.1101/2021.04.08.21255167; this version posted April 13, 2021. The copyright holder for this preprint (which was not certified by peer review) is the author/funder, who has granted medRxiv a license to display the preprint in perpetuity. It is made available under a CC-BY-NC-ND 4.0 International license .

316 The high prevalence of probable anxiety and depression disorders $(36.7 \%$ and $43.3 \%$ 317 respectively) are striking. A cohort study in the United Kingdom revealed that the incidence 318 of probable anxiety and depression disorder in the general population was $24 \%$ and $18.1 \%$ 319 during the pandemic (26). A history of reported COVID-19 was associated with increased 320 risk anxiety and depression. We also highlighted a high rate of probable PTSD (33.3\%), 321 which is similar to the $30.8 \%$ prevalence in a US study (27). PTSD reflects the hardship of 322 the patient's experience with COVID-19. The persistence of physical symptoms (related or 323 not to COVID-19) is likely associated with the psychological burden of the pandemic, 324 synergistically contributing to the emergence of "long-COVID", and may explain the high 325 prevalence of psychological disorders in our cohort.

326 Long-COVID is an ill-defined condition characterized by symptoms persisting for at least 4 327 to 12 weeks after SARS-CoV-2 infection, depending on the study (10,13). Excluding 328 alternate diagnoses is crucial because objective evidence of previous COVID-19 may not be 329 mandatory for the diagnosis of long-COVID $(13,20)$. Deep phenotyping of our patients did 330 not lead to alternative diagnoses in all patients. Long-COVID mainly represents patients with 331 non-severe initial presentations (12), and its pathophysiology is likely multifactorial. For non332 hospitalized long-COVID patients, physical deconditioning (28), psychological disorders 333 (29), viral encephalitis (7), dysautonomia (30), and immunological abnormalities are 334 plausible suspects and could co-exist. Indeed, auto-immunity has been demonstrated 335 following COVID-19 (31,32). However, viral-induced autoimmunity is likely transient, as 336 demonstrated by the negative repeat screening for antiphospholipid antibodies in 8 initially 337 positive patients, as well as the lack of significant increase in cytokine/IFN- $\alpha 2$ levels and 338 clinical/biological signs of autoimmune disease. Further studies will need to explore other 339 potential mechanisms at play in such patients (e.g., dysautonomia, neurological studies). 
medRxiv preprint doi: https://doi.org/10.1101/2021.04.08.21255167; this version posted April 13, 2021. The copyright holder for this preprint

(which was not certified by peer review) is the author/funder, who has granted medRxiv a license to display the preprint in perpetuity.

It is made available under a CC-BY-NC-ND 4.0 International license .

340 This study has limitations. First, we included 30 consecutive patients, which may not allow to

341 capture the complexity of long-COVID. However, this number allowed for a multimodal

342 evaluation without missing data, and the consecutive recruitment limited potential selection

343 bias. Given our study design, we cannot infer the prevalence of long-COVID, which has been

344 evaluated at $10 \%$ in the United Kingdom (10). Only 9 patients had a RT-PCR test in our

345 cohort in the 5 weeks after symptom onset, because RT-PCR tests were not available for mild

346 diseases during the first epidemic wave in France. Finally, we cannot exclude that our design

347 implied a selection bias of patients with psychological distress. However, our study allowed

348 for accurately evaluating the patients seeking medical advice for persistent symptoms self-

349 attributed to long-COVID and will therefore be of use for clinicians who may be under-

350 prepared to answer these patients' questions. Although no treatment has been approved for

351 long-COVID, more than half of our patients reported a spontaneous and gradual

352 improvement of symptoms over time, which provides a window of hope for these patients.

353 To conclude, our study sheds light on the burden experienced by patients reporting long-term

354 symptoms self-attributed to COVID-19, as well as some of the mechanisms at play. A better

355 recognition and understanding of long-COVID will help healthcare providers care for these

356 patients.

357

358 
medRxiv preprint doi: https://doi.org/10.1101/2021.04.08.21255167; this version posted April 13, 2021. The copyright holder for this preprint (which was not certified by peer review) is the author/funder, who has granted medRxiv a license to display the preprint in perpetuity.

It is made available under a CC-BY-NC-ND 4.0 International license .

359

360

361

362

363

364

365

366

367

368

369

370

371

372

373

374

375

376

377

378

379

380

381

382

383

384

385

386

387

388

389

390

391

392

393

394

395

396

397

\section{References}

1. Carfì A, Bernabei R, Landi F, for the Gemelli Against COVID-19 Post-Acute Care Study Group. Persistent Symptoms in Patients After Acute COVID-19. JAMA. 11 août 2020;324(6):603.

2. Living with Covid19 [Internet]. National Institute for Health Research; 2020 oct [cité 13 nov 2020]. Disponible sur: https://evidence.nihr.ac.uk/themedreview/living-withcovid19/

3. Covid Long Haulers Describe the Devastating Aftereffects of the Disease. Bloomberg.com [Internet]. 9 nov 2020 [cité 5 déc 2020]; Disponible sur: https://www.bloomberg.com/news/features/2020-11-09/coronavirus-long-haulers-tellus-their-symptoms-and-the-aftereffects-of-disease

4. Long Covid: 'Is this now me forever?' [Internet]. the Guardian. 2020 [cité 5 déc 2020]. Disponible sur: http://www.theguardian.com/world/2020/nov/29/eleanor-morgan-isstill-struggling-with-long-covid-months-after-catching-the-virus

5. Guo T, Fan Y, Chen M, Wu X, Zhang L, He T, et al. Cardiovascular Implications of Fatal Outcomes of Patients With Coronavirus Disease 2019 (COVID-19). JAMA Cardiol. 1 juill 2020;5(7):811.

6. Salehi S, Reddy S, Gholamrezanezhad A. Long-term Pulmonary Consequences of Coronavirus Disease 2019 (COVID-19): What We Know and What to Expect. J Thorac Imaging. juill 2020;35(4):W87?9.

7. Pero A, Ng S, Cai D. COVID-19: A Perspective from Clinical Neurology and Neuroscience. The Neuroscientist. oct 2020;26(506):387091.

8. Chopra V, Flanders SA, O'Malley M, Malani AN, Prescott HC. Sixty-Day Outcomes Among Patients Hospitalized With COVID-19. Ann Intern Med [Internet]. 11 nov 2020 [cité 13 nov 2020]; Disponible sur: https://www.acpjournals.org/doi/10.7326/M20-5661

9. Huang C, Huang L, Wang Y, Li X, Ren L, Gu X, et al. 6-month consequences of COVID-19 in patients discharged from hospital: a cohort study. The Lancet. 16 janv 2021;397(10270):220?32.

10. Prevalence of long COVID symptoms and COVID-19 complications - Office for National Statistics [Internet]. [cité 16 déc 2020]. Disponible sur: https://www.ons.gov.uk/peoplepopulationandcommunity/healthandsocialcare/healthandl ifeexpectancies/datasets/prevalenceoflongcovidsymptomsandcovid19complications

11. Yelin D, Wirtheim E, Vetter P, Kalil AC, Bruchfeld J, Runold M, et al. Long-term consequences of COVID-19: research needs. Lancet Infect Dis. 1 oct 2020;20(10):1115?7.

12. Davis HE, Assaf GS, McCorkell L, Wei H, Low RJ, Re'em Y, et al. Characterizing Long COVID in an International Cohort: 7 Months of Symptoms and Their Impact. medRxiv. 27 déc 2020;2020.12.24.20248802. 
medRxiv preprint doi: https://doi.org/10.1101/2021.04.08.21255167; this version posted April 13, 2021. The copyright holder for this preprint (which was not certified by peer review) is the author/funder, who has granted medRxiv a license to display the preprint in perpetuity.

It is made available under a CC-BY-NC-ND 4.0 International license .

398

399

400

401

402

403

404

405

406

407

408

409

410

411

412

413

414

415

416

417

418

419

420

421

422

423

424

425

426

427

428

429

430

431

432

433

434

435

13. Raveendran AV. Long COVID-19: Challenges in the diagnosis and proposed diagnostic criteria. Diabetes Metab Syndr Clin Res Rev. janv 2021;15(1):14506.

14. Salje H, Kiem CT, Lefrancq N, Courtejoie N, Bosetti P, Paireau J, et al. Estimating the burden of SARS-CoV-2 in France. Science. 10 juill 2020;369(6500):208?11.

15. Cruccu G, Sommer C, Anand P, Attal N, Baron R, Garcia-Larrea L, et al. EFNS guidelines on neuropathic pain assessment: revised 2009: Neuropathic pain assessment. Eur J Neurol. août 2010;17(8):1010?8.

16. Perrot S, Bouhassira D, Fermanian J. Development and validation of the Fibromyalgia Rapid Screening Tool (FiRST): Pain. août 2010;150(2):250?6.

17. Rodero MP, Decalf J, Bondet V, Hunt D, Rice GI, Werneke S, et al. Detection of interferon alpha protein reveals differential levels and cellular sources in disease. J Exp Med. 1 mai 2017;214(5):1547?55.

18. Roberge P. A psychometric evaluation of the French Canadian version of the Hospital Anxiety and Depression Scale in a large primary care population. J Affect Disord. $2013 ; 9$.

19. Bovin MJ, Marx BP, Weathers FW, Gallagher MW, Rodriguez P, Schnurr PP, et al. Psychometric properties of the PTSD Checklist for Diagnostic and Statistical Manual of Mental Disorders-Fifth Edition (PCL-5) in veterans. Psychol Assess. nov 2016;28(11):1379091.

20. Greenhalgh T, Knight M, A'Court C, Buxton M, Husain L. Management of post-acute covid-19 in primary care. BMJ. 11 août 2020;m3026.

21. Ladds E, Rushforth A, Wieringa S, Taylor S, Rayner C, Husain L, et al. Persistent symptoms after Covid-19: qualitative study of 114 "long Covid" patients and draft quality principles for services. BMC Health Serv Res. 20 déc 2020;20(1):1144.

22. Schwarzkopf S, Krawczyk A, Knop D, Klump H, Heinold A, Heinemann FM, et al. Early Release - Cellular Immunity in COVID-19 Convalescents with PCR-Confirmed Infection but with Undetectable SARS-CoV-2-Specific IgG - Volume 27, Number 1January 2021 - Emerging Infectious Diseases journal - CDC. [cité 24 nov 2020]; Disponible sur: https://wwwnc.cdc.gov/eid/article/27/1/20-3772_article

23. Ibarrondo FJ, Fulcher JA, Goodman-Meza D, Elliott J, Hofmann C, Hausner MA, et al. Rapid Decay of Anti-SARS-CoV-2 Antibodies in Persons with Mild Covid-19. N Engl J Med. 10 sept 2020;383(11):1085 ?7.

24. Tonn T, Corman VM, Johnsen M, Richter A, Rodionov RN, Drosten C, et al. Stability and neutralising capacity of SARS-CoV-2-specific antibodies in convalescent plasma. Lancet Microbe. 1 juin 2020;1(2):e63.

25. Amanzio M, Howick J, Bartoli M, Cipriani GE, Kong J. How Do Nocebo Phenomena Provide a Theoretical Framework for the COVID-19 Pandemic? Front Psychol. 30 oct 2020;11:589884. 
medRxiv preprint doi: https://doi.org/10.1101/2021.04.08.21255167; this version posted April 13, 2021. The copyright holder for this preprint

(which was not certified by peer review) is the author/funder, who has granted medRxiv a license to display the preprint in perpetuity.

It is made available under a CC-BY-NC-ND 4.0 International license .

436

437

438

439

440

441

442

443

444

445

446

447

448

449

450

451

452

453

454

455

456

457

458

459

460

461

462

463

464

465

466

467

468

469

470

471

472
26. Kwong ASF, Pearson RM, Adams MJ, Northstone K, Tilling K, Smith D, et al. Mental health before and during COVID-19 in two longitudinal UK population cohorts. Br J Psychiatry. 24 nov 2020;1?27.

27. Liu CH, Zhang E, Wong GTF, Hyun S, Hahm H "Chris". Factors associated with depression, anxiety, and PTSD symptomatology during the COVID-19 pandemic: Clinical implications for U.S. young adult mental health. Psychiatry Res. août 2020;290:113172.

28. Covid-19 will be followed by a deconditioning pandemic [Internet]. The BMJ. 2020 [cité 3 janv 2021]. Disponible sur: https://blogs.bmj.com/bmj/2020/06/15/covid-19-willbe-followed-by-a-deconditioning-pandemic/

29. Butler M, Pollak TA, Rooney AG, Michael BD, Nicholson TR. Neuropsychiatric complications of covid-19. BMJ. 13 oct 2020;371:m3871.

30. Dani M, Dirksen A, Taraborrelli P, Torocastro M, Panagopoulos D, Sutton R, et al. Autonomic dysfunction in 'long COVID': rationale, physiology and management strategies. Clin Med [Internet]. 26 nov 2020 [cité 2 janv 2021]; Disponible sur: https://www.rcpjournals.org/content/clinmedicine/early/2020/11/26/clinmed.2020-0896

31. Wang EY, Mao T, Klein J, Dai Y, Huck JD, Liu F, et al. Diverse Functional Autoantibodies in Patients with COVID-19 [Internet]. Infectious Diseases (except HIV/AIDS); 2020 déc [cité 3 janv 2021]. Disponible sur: http://medrxiv.org/lookup/doi/10.1101/2020.12.10.20247205

32. Bastard P, Rosen LB, Zhang Q, Michailidis E, Hoffmann H-H, Zhang Y, et al. Autoantibodies against type I IFNs in patients with life-threatening COVID-19. Science [Internet]. 23 oct 2020 [cité 3 janv 2021];370(6515). Disponible sur: https://science.sciencemag.org/content/370/6515/eabd4585

\section{Authors contributions :}

MS, RF, JS, EC and LP recruited and evaluated clinically the patients. FG, CN and SFK conducted the virological evaluations. AM, AG and PV participated in the psychiatric evaluation. RAM conducted the psychological evaluation. SBT, RC, STA, MP, AB and SB conducted the immunological assays (cytokines). LA, JEG helped in the design of the study and critically reviewed the manuscript. MS, RF, FG, RFK and JS wrote the manuscript. MS, RF and FG are co-first authors. RFK and JS are co-last authors.

\section{Funding source :}

None to disclose. 
medRxiv preprint doi: https://doi.org/10.1101/2021.04.08.21255167; this version posted April 13, 2021. The copyright holder for this preprint (which was not certified by peer review) is the author/funder, who has granted medRxiv a license to display the preprint in perpetuity.

It is made available under a CC-BY-NC-ND 4.0 International license .

A

Clinical features

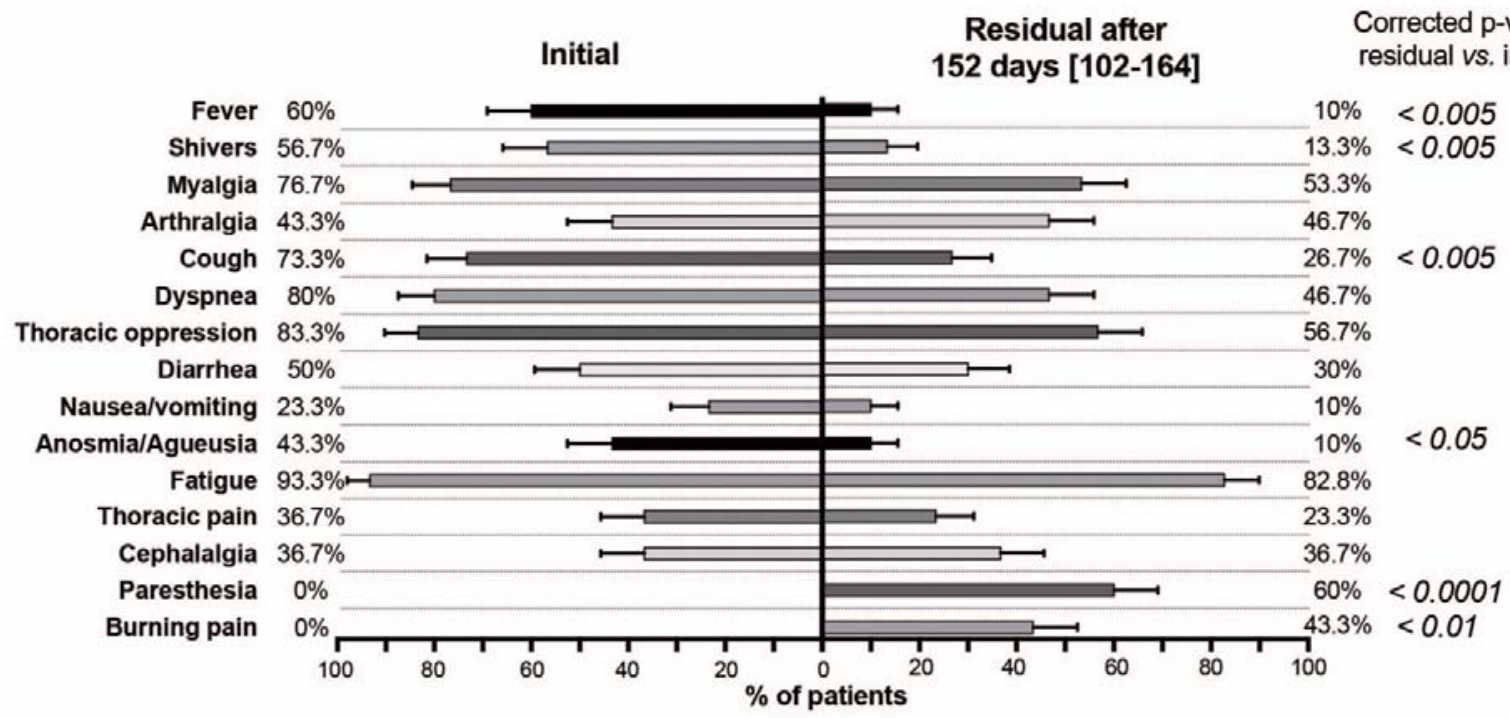

B

\section{Clinical features}

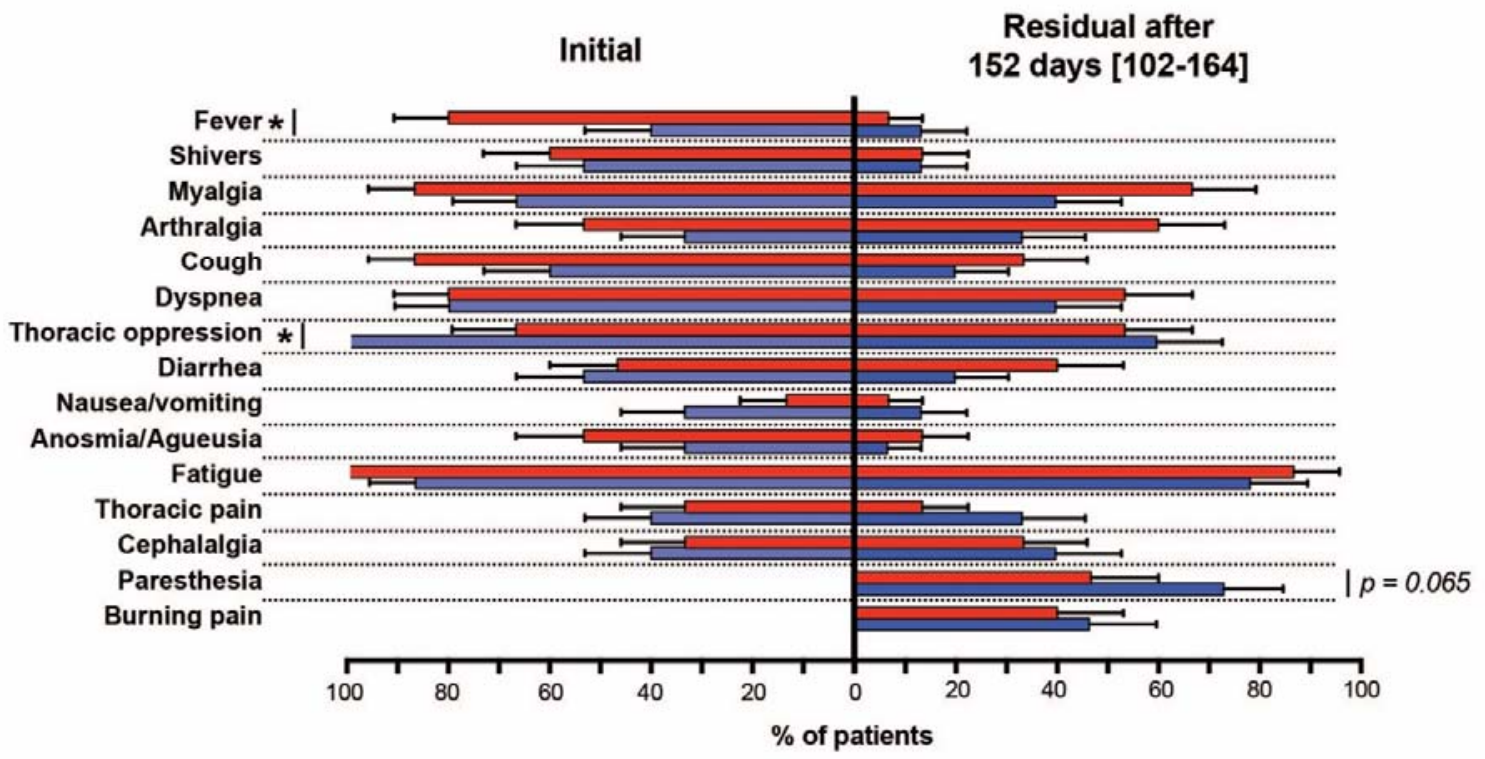

473

474

475

476

477

478

479

480

481

482

483

484

\section{Non-immunized}

Figure 1: Initial and residual clinical features of patients with persistent symptoms selfattributed to COVID-19.

(A) Residual symptoms collected at a median of 152 days [interquartile range (IQR) 102164] after initial presentation ( $n=30$ patients). Columns indicate symptom prevalence and bars are mean \pm standard error measure. P-values were calculated with McNemar's test with Bonferroni correction for multiple analysis.

(B) Comparison of initial/residual symptoms between immunized and non-immunized patients. Columns indicate symptom prevalence in immunized (defined by ELISA or serology; red) and non-immunized patients; bars are mean \pm standard error measure. $*_{p}<0.05$ by chi-square or Fisher's exact test (if appropriate). 
medRxiv preprint doi: https://doi.org/10.1101/2021.04.08.21255167; this version posted April 13, 2021. The copyright holder for this preprint (which was not certified by peer review) is the author/funder, who has granted medRxiv a license to display the preprint in perpetuity.

It is made available under a CC-BY-NC-ND 4.0 International license .

A Serologic assays

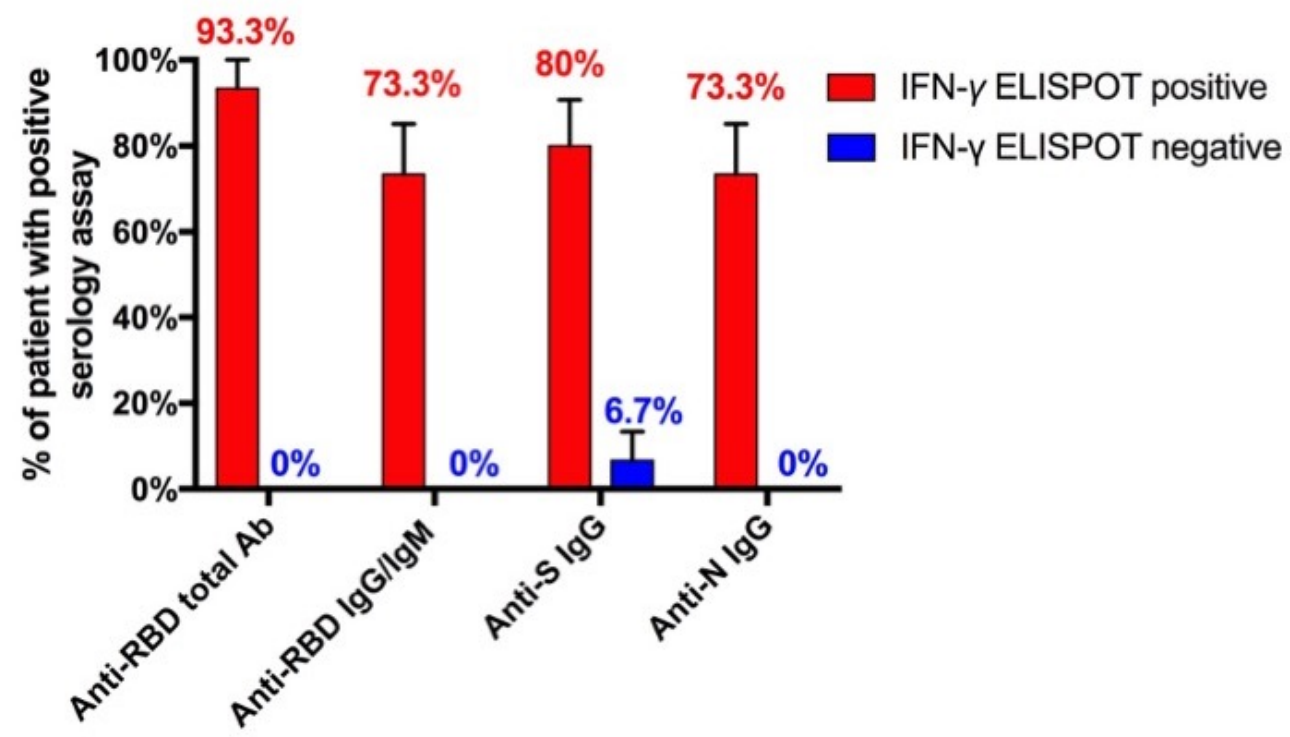

B Immunized $(n=15)$

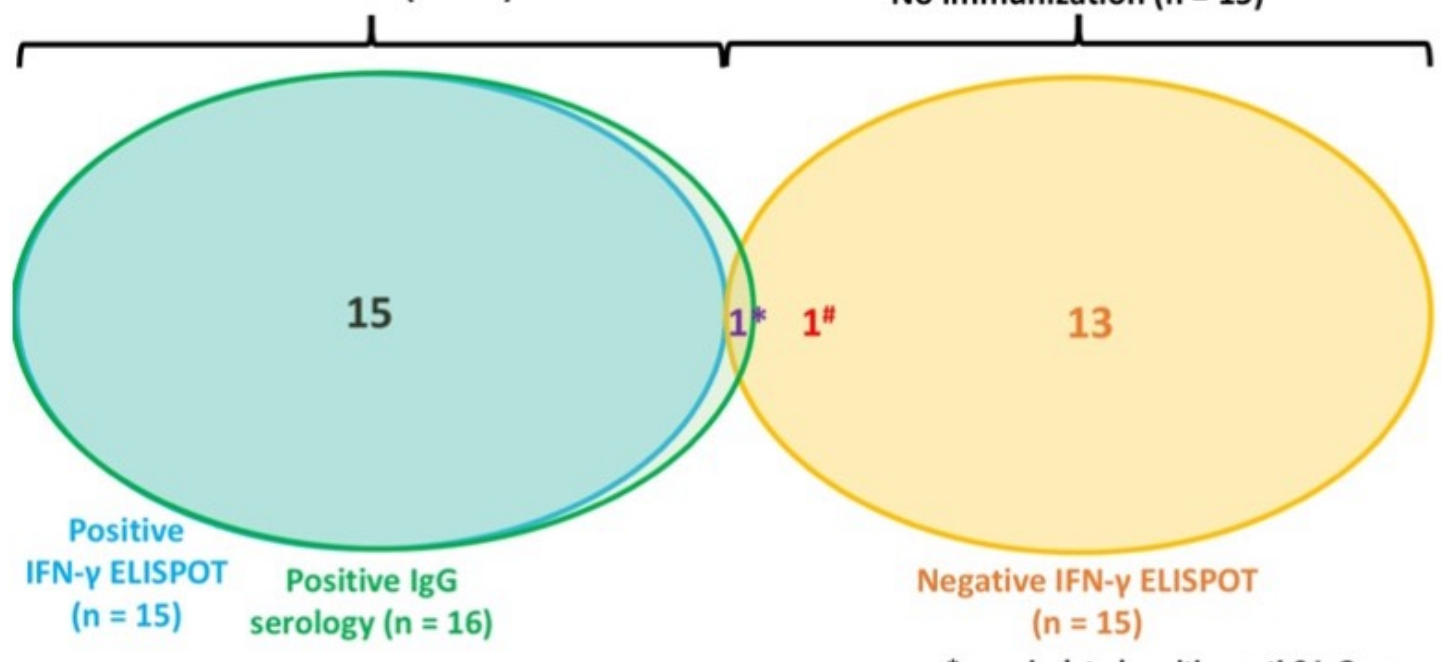

*, one isolated positive anti-S IgG assay \#, positive nasopharyngeal RT-PCR at presentation

Figure 2: Specific immunological responses to SARS-CoV-2 in 30 patients reporting persistent symptoms self-attributed to long-COVID.

(A) Results of SARS-CoV-2 serologic assays based on the interferon- $\gamma($ IFN- $\gamma)$ ELISPOTresults ( $n=15 /$ group). Anti-RBD total antibody (Wantai total antibody); anti-RBD IgG/IgM (Biosynex BSS IgM/IgG assay); anti-S IgG (Euroimmun); anti-N IgG (Abbott Architect). Data are mean \pm standard error measure prevalence of test positivity.

(B) Two patterns of patients were identified: those with objective signs of SARS-CoV-2 immunity (cellular and humoral response, $n=15)$ and those without $(n=15)$. Positive IgG was defined as a positive result against spike, receptor binding domain or nucleocapsid protein. 
medRxiv preprint doi: https://doi.org/10.1101/2021.04.08.21255167; this version posted April 13, 2021. The copyright holder for this preprint (which was not certified by peer review) is the author/funder, who has granted medRxiv a license to display the preprint in perpetuity. It is made available under a CC-BY-NC-ND 4.0 International license.

*, One patient with virologically unproven initial presentation had an isolated anti-S IgG-positive assay result. IFN- $\gamma$ ELISPOT and all other serological tests were negative.

500

\#, One with a virologically-proven initial presentation had negative SARS-CoV-2

501 ELISPOT (conducted at day 140) and serological assays (conducted at days 37, 85 and 140). 


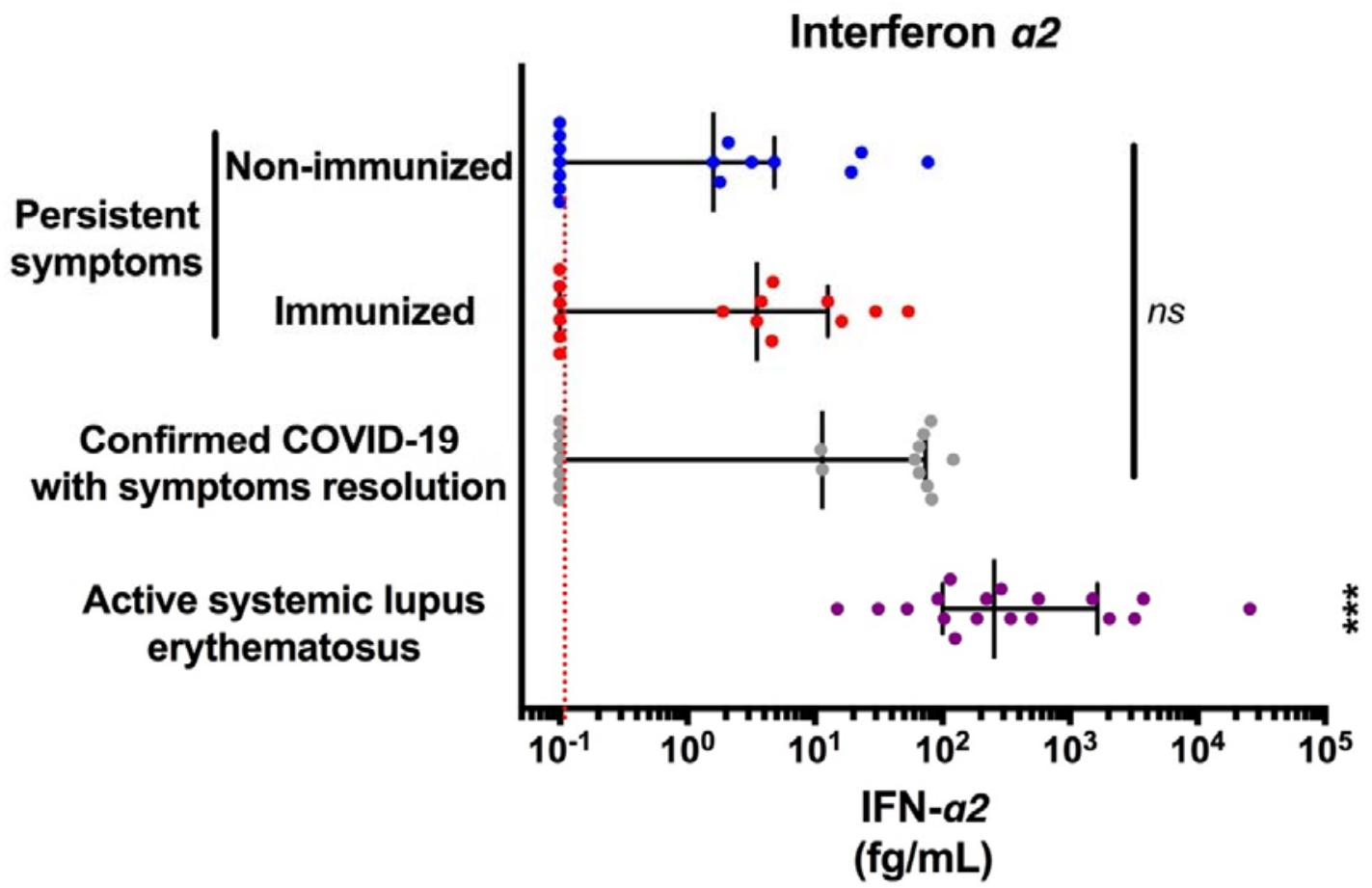

506 Figure 3: Normal levels of IFN- 22 for patients with persistent symptoms attributed to 507 COVID-19. Ultra-sensitive IFN- $\alpha$ levels were measured by using SIMOA in patients with 508 persistent symptoms self-attributed to COVID-19. As a comparison, IFN- $\alpha 2$ levels of 509 individuals with confirmed previous COVID-19 (serology and IFN- $\gamma$ positive) without 510 persistent symptoms (sampled at least 12 weeks after; $\mathrm{n}=17$ ) and patients with active 511 systemic lupus erythematosus $(n=18)$. Each point corresponds to a single patient; the 512 central bar shows medians with interquartile ranges. The red dotted line shows the lower 513 limit of detection. ns, non-significant; ***, $p<0.001$ versus all other groups by non514 parametric Kruskal-Wallis test with Dunn's correction for multiple testing. 
medRxiv preprint doi: https://doi.org/10.1101/2021.04.08.21255167; this version posted April 13, 2021. The copyright holder for this preprint (which was not certified by peer review) is the author/funder, who has granted medRxiv a license to display the preprint in perpetuity.

It is made available under a CC-BY-NC-ND 4.0 International license .

516

517

518

519

520

521
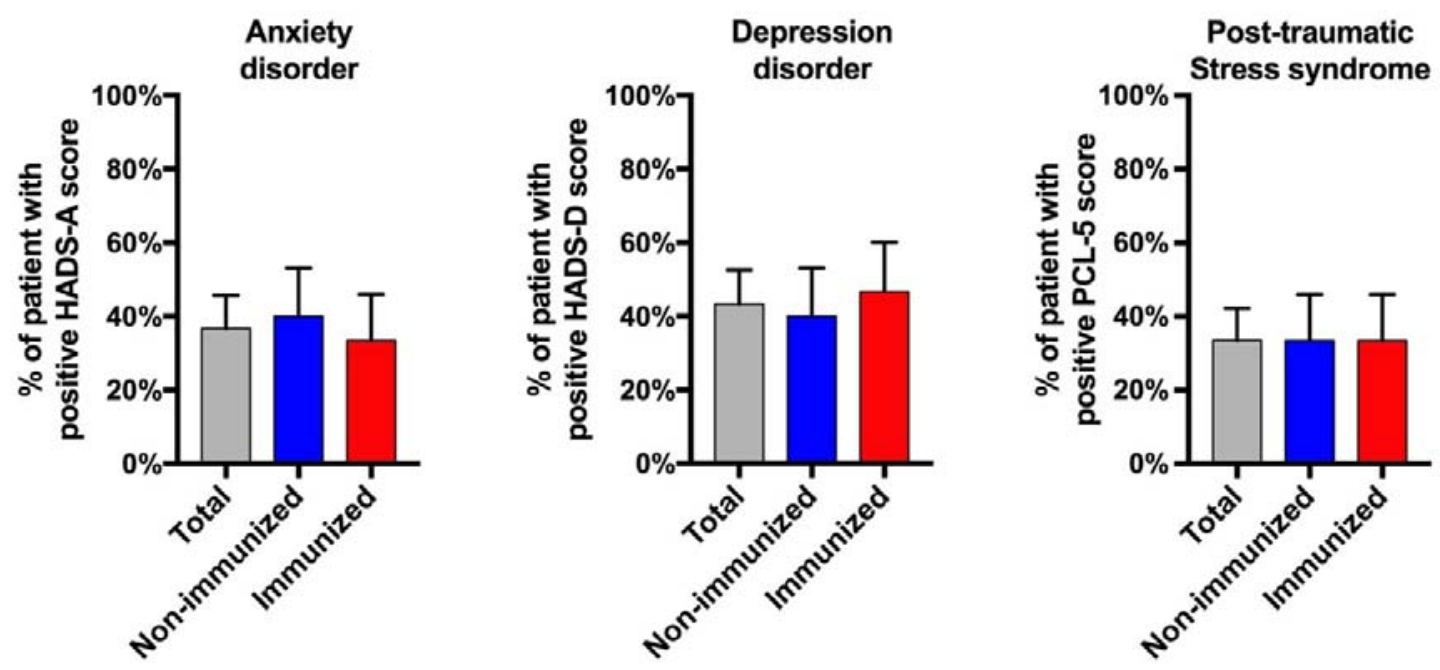

Figure 4: Prevalence of anxiety/depression disorders and post-traumatic stress syndrome in patients seeking medical help for persistent symptoms self-attributed to COVID-19. Data are mean \pm standard error measure prevalence. 
medRxiv preprint doi: https://doi.org/10.1101/2021.04.08.21255167; this version posted April 13, 2021. The copyright holder for this preprint (which was not certified by peer review) is the author/funder, who has granted medRxiv a license to display the preprint in perpetuity.

It is made available under a CC-BY-NC-ND 4.0 International license .

522 Table 1: Characteristics of the whole population and patients with or without cellular 523 and/or humoral immunization.

524

\begin{tabular}{|c|c|c|c|c|}
\hline Characteristics & $\begin{array}{l}\text { Total } \\
\text { population } \\
(\mathrm{n}=30)\end{array}$ & $\begin{array}{l}\text { Immunized } \\
(\mathrm{n}=15)\end{array}$ & $\begin{array}{l}\text { Non-immunized } \\
(\mathrm{n}=15)\end{array}$ & \begin{tabular}{|l|}
$\mathrm{p}-$ \\
value
\end{tabular} \\
\hline \multicolumn{5}{|l|}{ Demographics } \\
\hline Age (median, IQR) & $40[35-54]$ & $40[31-58]$ & 39 [35-45] & $n s$ \\
\hline Female sex & $60 \%(18)$ & $46.7 \%(7)$ & $73.3(11)$ & 0.14 \\
\hline $\begin{array}{l}\text { Close contact with confirmed } \\
\text { COVID- } 19 \text { patients }\end{array}$ & $43.3 \%(13 / 30)$ & $46.7 \%(7 / 15)$ & $40 \%(6 / 15)$ & $n s$ \\
\hline \multicolumn{5}{|l|}{$\begin{array}{l}\text { Risk factors for severe } \\
\text { SARS-CoV-2 infection } \\
\text { (history of) }\end{array}$} \\
\hline $\begin{array}{c}\text { BMI }\left(\mathrm{kg} / \mathrm{m}^{2}\right),(\text { median, IQR }) \\
\quad>25 \\
\quad>30\end{array}$ & $\begin{array}{l}22.6[20.4-26.3] \\
30 \%(9) \\
20 \%(6)\end{array}$ & $\begin{array}{l}23.6[21.2-27.8] \\
40 \% \\
26.7 \%\end{array}$ & $\begin{array}{l}22.4[19.6-24.5] \\
20 \% \\
13.3 \%\end{array}$ & $n s$ \\
\hline Diabetes & $10 \%(3)$ & $13.3 \%(2)$ & $6.7 \%(1)$ & $n s$ \\
\hline Hypertension & $3.3 \%(1)$ & $6.7 \%(1)$ & $0 \%$ & $n s$ \\
\hline Myocardial infarction & $0 \%$ & & & $n s$ \\
\hline Cerebrovascular event & $6.7 \%(1)$ & $13.3 \%(2)$ & $0 \%$ & $n s$ \\
\hline Respiratory disease & $0 \%$ & & & $n s$ \\
\hline Renal failure & $0 \%$ & & & $n s$ \\
\hline Liver failure & $0 \%$ & & & $n s$ \\
\hline Cancer & $3.3 \%(1)$ & $6.7 \%(1)$ & $0 \%$ & $n s$ \\
\hline $\begin{array}{l}\text { Smoking } \\
\text { History } \\
\text { Active } \\
\end{array}$ & $\begin{array}{l}43.3 \%(13) \\
3.3 \%(1)\end{array}$ & $\begin{array}{l}53.3 \%(8) \\
0 \%\end{array}$ & $\begin{array}{l}33.3 \%(5) \\
6.7 \%(1)\end{array}$ & $n s$ \\
\hline \multicolumn{5}{|l|}{ Socio-economic } \\
\hline Married & $28.6 \%$ & $30.8 \%$ & $26.7 \%$ & $n s$ \\
\hline $\begin{array}{l}\text { Working status } \\
\text { Currently working } \\
\text { Unemployed } \\
\text { Retired }\end{array}$ & $\begin{array}{l}83.3 \% \\
10 \% \\
6.67 \% \\
\end{array}$ & $\begin{array}{l}66.7 \% \\
20 \% \\
13.3 \% \\
\end{array}$ & $\begin{array}{l}100 \% \\
0 \% \\
0 \% \\
\end{array}$ & $n s$ \\
\hline $\begin{array}{l}\text { Education level } \\
\text { Below high school } \\
\text { High school } \\
\leq 3 \text { years post-high } \\
\text { school } \\
\text { College graduate }\end{array}$ & $\begin{array}{l}6.7 \% \\
16.7 \% \\
26.7 \% \\
\\
50 \%\end{array}$ & $\begin{array}{l}13.3 \% \\
26.7 \% \\
13.3 \% \\
46.7 \%\end{array}$ & $\begin{array}{l}0 \% \\
6.7 \% \\
40 \% \\
53.3 \%\end{array}$ & $n s$ \\
\hline
\end{tabular}

BMI, body mass index; ns, not significant 
medRxiv preprint doi: https://doi.org/10.1101/2021.04.08.21255167; this version posted April 13, 2021. The copyright holder for this preprint (which was not certified by peer review) is the author/funder, who has granted medRxiv a license to display the preprint in perpetuity.

It is made available under a CC-BY-NC-ND 4.0 International license .

530 Table 2: Psychological evaluation of the whole population and patients with and without 531 cellular and/or humoral immunization.

532

\begin{tabular}{|c|c|c|c|c|}
\hline Psychological evaluation & $\begin{array}{c}\text { Total } \\
\text { population } \\
(\mathrm{n}=30)\end{array}$ & $\begin{array}{c}\text { Immunized } \\
(\mathrm{n}=15)\end{array}$ & $\begin{array}{l}\text { Non- } \\
\text { immunized } \\
(n=15)\end{array}$ & p-value \\
\hline \multicolumn{5}{|l|}{ History } \\
\hline Depression disorder & $10 \%(3)$ & $6.7 \%(1)$ & $13.3 \%(2)$ & $n s$ \\
\hline Anxiety disorder & $26.7 \%(8)$ & $26.7 \%(4)$ & $26.7 \%(4)$ & $n s$ \\
\hline \multicolumn{5}{|l|}{ Context } \\
\hline Loss of job due to pandemic & $16.7 \%(5)$ & $20 \%(3)$ & $13.3 \%(2)$ & $n s$ \\
\hline Financial difficulties & $23.3 \%(7)$ & $20 \%(3)$ & $26.7 \%(4)$ & $n s$ \\
\hline $\begin{array}{l}\text { Death of close-ones due to } \\
\text { COVID-19 }\end{array}$ & $0 \%$ & & & \\
\hline \multicolumn{5}{|l|}{ Symptoms } \\
\hline Sleep issues & $76.7 \%(23)$ & $80 \%(12)$ & $73.3 \%(11)$ & $n s$ \\
\hline Use of anxiolytics & $13.3 \%(4)$ & $20 \%(3)$ & $6.7 \%(1)$ & $n s$ \\
\hline $\begin{array}{l}\text { Increased alcohol/tobacco use } \\
\text { after diagnosis }\end{array}$ & $6.7 \%(2)$ & $13.3 \%(2)$ & $0 \%$ & $n s$ \\
\hline $\begin{array}{l}\text { Probable anxiety disorder } \\
\text { (HADS-A } \geq 10)\end{array}$ & $36.6 \%(11)$ & $33.3 \%(5)$ & $40 \%(6)$ & $n s$ \\
\hline $\begin{array}{l}\text { Probable depression disorder } \\
\text { (HADS-D } \geq 7 \text { ) }\end{array}$ & $43.3 \%(13)$ & $46.6 \%(7)$ & $40 \%(6)$ & $n s$ \\
\hline $\begin{array}{l}\text { Probable post-traumatic stress } \\
\text { syndrome } \\
(\text { PCL-5 } \geq 31)\end{array}$ & $30 \%(9)$ & $33.3 \%(5)$ & $26.7 \%(4)$ & $n s$ \\
\hline \multicolumn{5}{|l|}{$\begin{array}{l}\text { Patients' perception* } \\
(\mathrm{N}=29)\end{array}$} \\
\hline COVID-19 is dangerous & $79.3 \%(23)$ & $85.7(12)$ & $73.3 \%(11)$ & $n s$ \\
\hline $\begin{array}{l}\text { COVID-19 pandemic is } \\
\text { worrisome }\end{array}$ & $41.4 \%(12)$ & $35.7 \%(5)$ & $46.7 \%(7)$ & $n s$ \\
\hline Support from family & $66.7 \%(20)$ & $73.3 \%(11)$ & $60 \%(9)$ & $n s$ \\
\hline Support from friends & $60 \%(18)$ & $73.3 \%(11)$ & $46.7 \%(7)$ & $n s$ \\
\hline Support from colleagues & $44 \%(11 / 25)$ & $36.4 \%(4 / 11)$ & $50 \%(7 / 14)$ & $n s$ \\
\hline Support from physicians & $20.7 \%(6)$ & $28.6 \%(4)$ & $13.3 \%(2)$ & $n s$ \\
\hline $\begin{array}{l}\text { Good acknowledgment from } \\
\text { the media }\end{array}$ & $10.3 \%(3)$ & $21.4 \%(3)$ & $0 \%$ & 0.10 \\
\hline $\begin{array}{l}\text { Good management of } \\
\text { pandemics by the authorities }\end{array}$ & $20.7 \%(6)$ & $35.7 \%(5)$ & $6.7 \%(1)$ & 0.08 \\
\hline
\end{tabular}

$533 *$, answers were recorded on a 1-5 scale, and positivity was considered with score $\geq 4$

534 HADS, Hospital Anxiety and Depression Scale; A, anxiety; D, depression 
Pain VAS
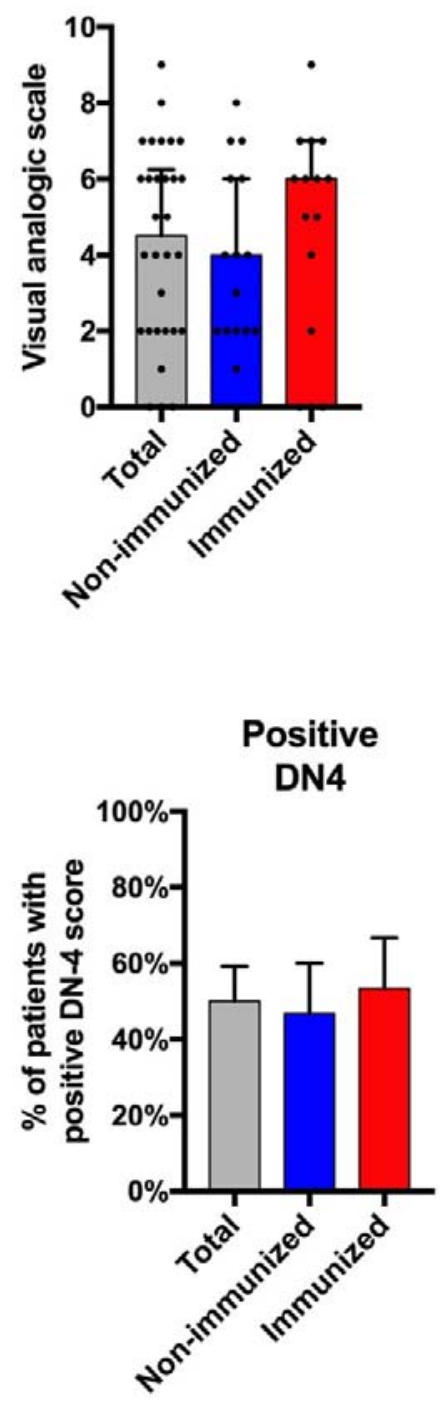

Fatigue VAS

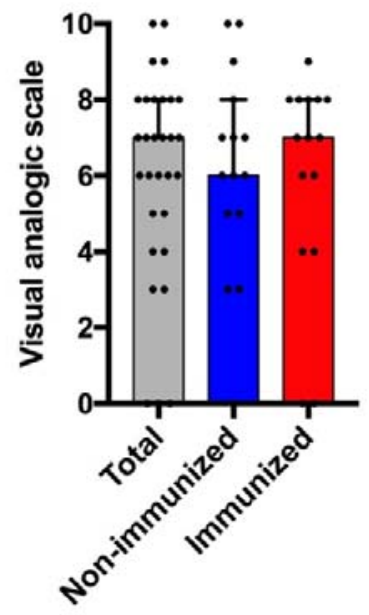

Positive

FIRST score

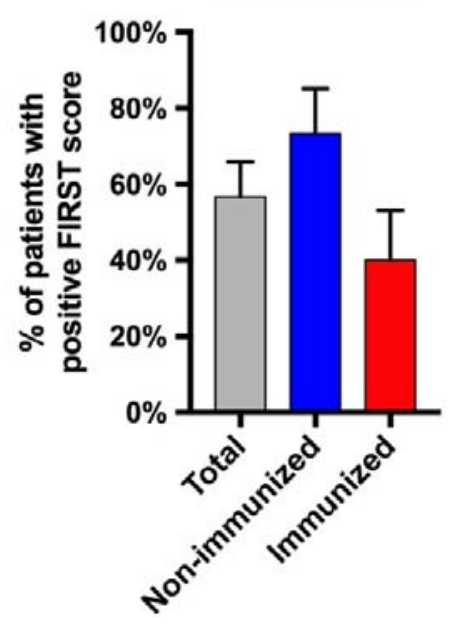

Dryness VAS

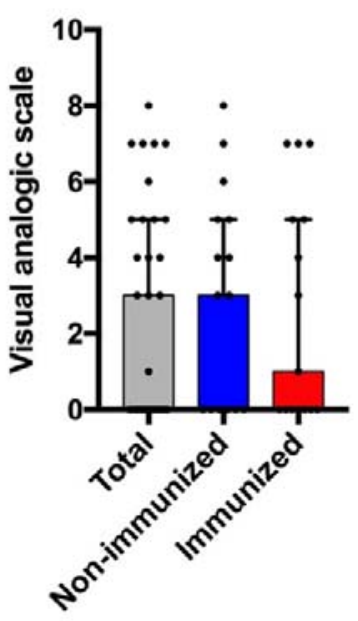

Health assessment questionaire

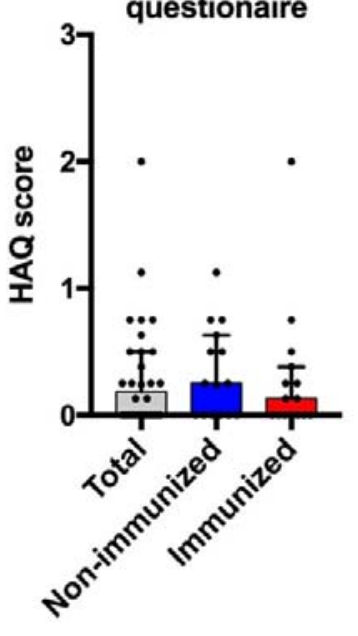

535
Supplementary figure 1: Comparison of pain, fatigue, dryness scores, DN4 and FiRST and Health Assessment Questionnaire (HAQ) scores in patients seeking medical help for persistent symptoms self-attributed to COVID-19. For continuous variables, data are median and interquartile range. For binary variables (DN4 and FiRST), data are mean \pm standard error measure prevalence of positivity. VAS, visual analog scale; FiRST, Fibromyalgia Rapid Screening Tool 
medRxiv preprint doi: https://doi.org/10.1101/2021.04.08.21255167; this version posted April 13, 2021. The copyright holder for this preprint (which was not certified by peer review) is the author/funder, who has granted medRxiv a license to display the preprint in perpetuity.

\section{Cytokine levels}

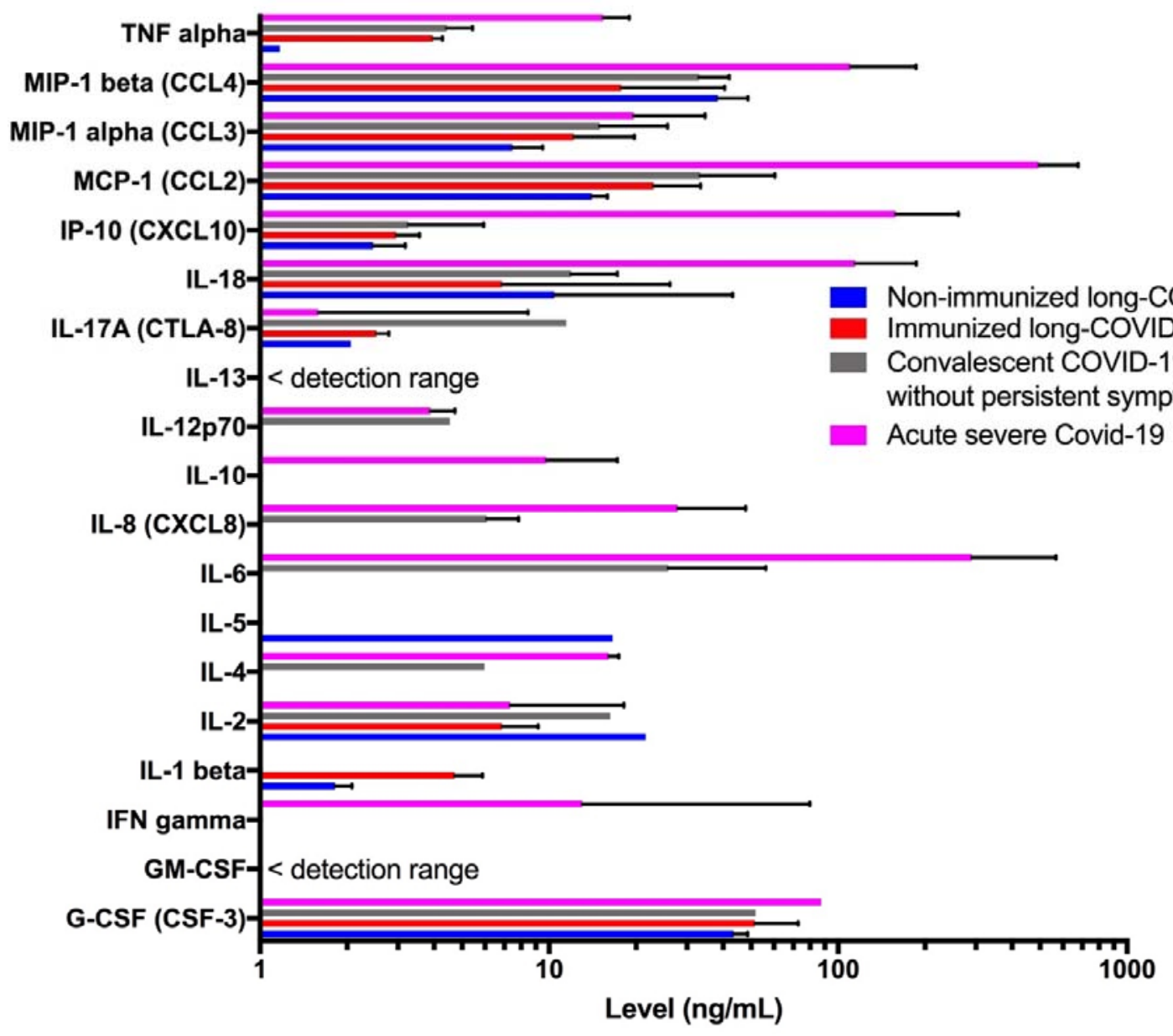

Supplementary figure 2: Cytokine levels in patients long-COVID patients compared to asymptomatic convalescent COVID-19 and acute severe COVID-19. Data are median and 546 bars indicate interquartile range.

547

548 
medRxiv preprint doi: https://doi.org/10.1101/2021.04.08.21255167; this version posted April 13, 2021. The copyright holder for this preprint (which was not certified by peer review) is the author/funder, who has granted medRxiv a license to display the preprint in perpetuity.

It is made available under a CC-BY-NC-ND 4.0 International license.
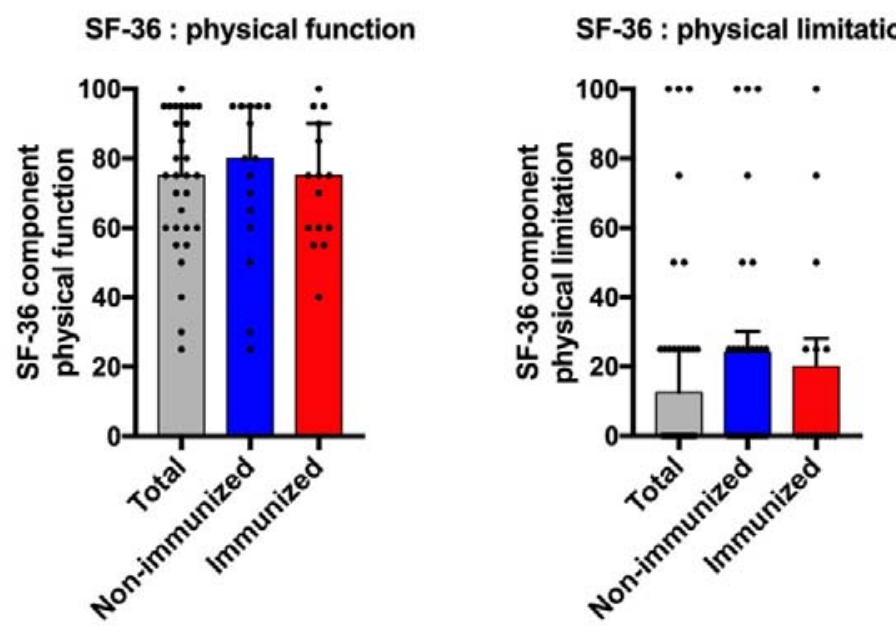

SF-36 : emotional limitation
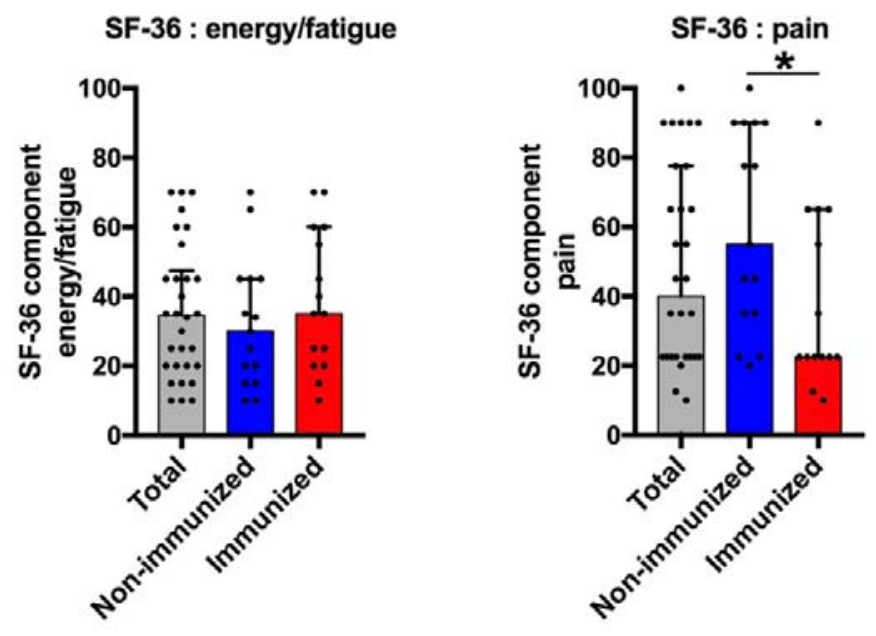

SF-36 : social functionning

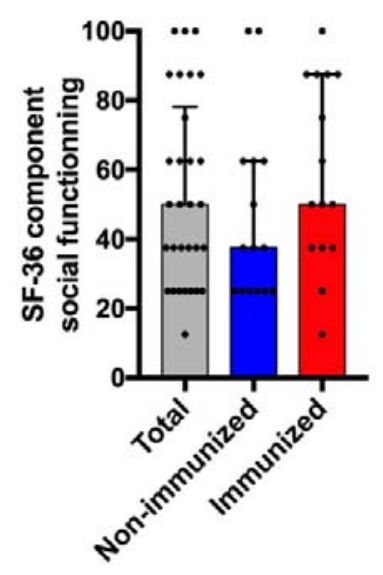

SF-36 : general health

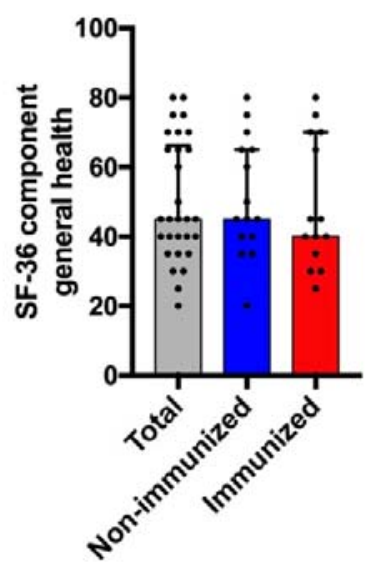

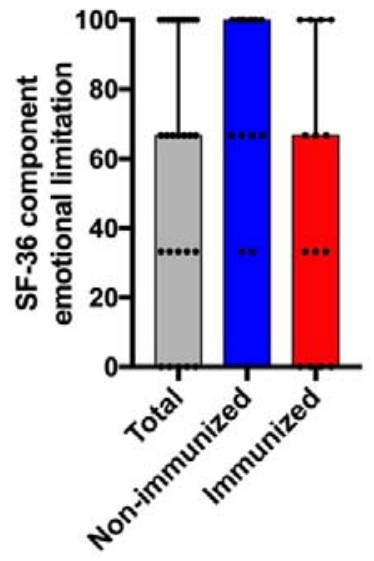

SF-36 : emotional wellbeing

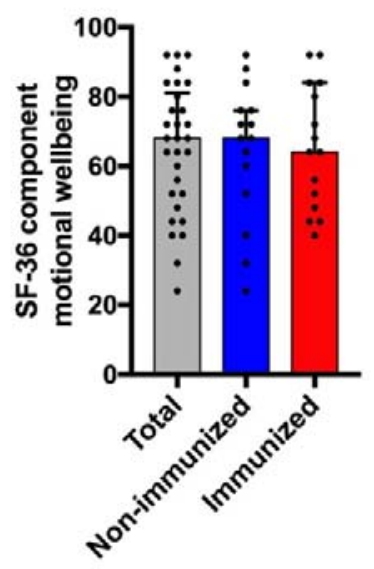

SF-36 : change in health

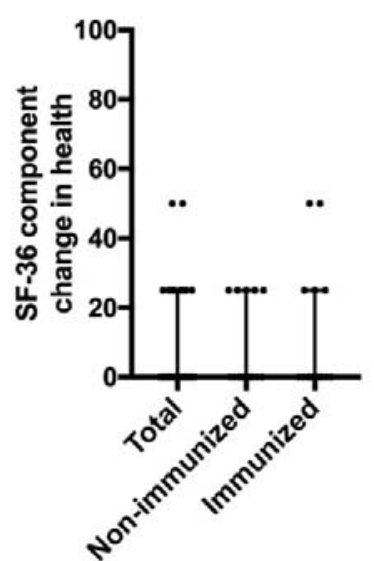


medRxiv preprint doi: https://doi.org/10.1101/2021.04.08.21255167; this version posted April 13, 2021. The copyright holder for this preprint

(which was not certified by peer review) is the author/funder, who has granted medRxiv a license to display the preprint in perpetuity.

It is made available under a CC-BY-NC-ND 4.0 International license .

\section{Supplementary file 1: Systematic bloodwork of long-COVID patients.}

- Hemogram

- Ionogram, calcium, phosphorus, creatinine, urea, angiotensin-converting enzyme

- Creatine phosphokinase, troponin I

560 - Urine protein and creatinine

561 - TSH, $25 \mathrm{OH}$ vitamin D, PTH

562 - TP, TCA, INR, D-dimers, fibrinogen

563

564

565

566

567

568

569

570

- Anti-nuclear antibodies (if $\geq 1 / 360$ : Extractable nuclear antibody and anti-doublestranded DNA were screened), rheumatoid factor, anti-citrullinated protein antibodies (ACPA using CCP2), ANCA, anti-cardiolipin, anti-beta-2 glycoprotein 1 antibodies and lupus anticoagulant.

- $\operatorname{IgG}, \operatorname{Ig} \mathrm{A}, \operatorname{IgM}$ levels

- C3-C4 and CH50

- HIV, HBV, HCV, CMV, EBV and Lyme (ELISA then western blot if positive) serology 